\title{
Fenomena Ibu dengan Kehamilan Risiko Tinggi: Mindfulness sebagai Alternatif Intervensi
}

\author{
Endang Fourianalistyawati \\ Fakultas Psikologi, Universitas YARSI \\ endang.fouriana@yarsi.ac.id
}

Kehamilan merupakan suatu perubahan yang transformatif. Wanita yang hamil mengalami perubahan fisik dan sekaligus perubahan emosi yang menyertai setiap trimester kehamilan tersebut. Wanita yang hamil muda merasa mual, muntah, meriang dan lemas. Rasa mual dan muntah ini berkurang sampai trimester pertama berakhir. Pada trimester kedua tubuh sudah mulai beradaptasi dan rasa mual dan muntah sudah berkurang. Akan tetapi pada trimester ketiga, keluhan yang diakibatkan oleh pembesaran perut, perubahan anatomis dan perubahan hormonal menyebabkan munculnya keluhan-keluhan pada ibu hamil (Venkata \& Venkateshiah, 2009).

Masalah kesehatan pada ibu hamil, baik secara fisik maupun psikis, memiliki dampak terhadap kualitas hidup Ibu hamil secara keseluruhan. Pada kondisi tertentu, masalah fisik dan psikis tersebut dapat meningkatkan risiko selama kehamilan, sekitar 5-10\% dari kehamilan termasuk kehamilan dengan risiko tinggi (Akhyar, 2010). Pada studi sebelumnya, peneliti menemukan bahwa sekitar $21,8 \%$ dari 55 ibu hamil dengan risiko tinggi memiliki kualitas hidup yang rendah, dan 63,6\% dengan tingkat kualitas hidup yang sedang (Fourianalistyawati \& Caninsti, 2014). Selain itu, pada ibu hamil yang mengalami depresi, diketahui juga memiliki korelasi negatif yang signifikan dengan kualitas hidup (Fauzy \& Fourianalistyawati, 2016).

Berdasarkan hal tersebut, ibu hamil khususnya dengan kasus risiko tinggi perlu menyiapkan diri dengan lebih memperhatikan kondisi kesehatannya dalam menghadapi kehamilan. Hasil penelitian terdahulu menunjukkan peningkatan kesejahteraan hidup selama masa kehamilan dengan pemberian intervensi berbasis mindfulness, khususnya dalam mengatasi rasa nyeri, mengurangi depresi, dan meningkatkan kemampuan orangtua dalam memberikan perhatian penuh pada bayi mereka yang baru lahir (Hughes, Williams, Bardacke, Duncan, Dimidjian, \& Goodman, 2009). Mindfulness merupakan kemampuan 
untuk menyadari dan fokus pada pengalaman saat ini pada diri individu, baik internal maupun eksternal (Brown \& Ryan, 2003). Pada intervensi yang dilakukan oleh peneliti dan tim, diketahui bahwa terdapat penurunan stres kehamilan pada kelompok eksperimen yang lebih besar daripada kelompok kontrol. Pada follow up yang dilakukan, diketahui bahwa peserta lebih tenang saat menjalani proses persalinan karena memiliki pemahaman dan kesadaran tentang proses melahirkan yang dijalani (Febriani, Fourianalistyawati \& Caninsti, 2017). Selain itu, diketahui juga bahwa self-compassion, dengan mindfulness sebagai salah satu aspek di dalamnya, secara bersama-sama dengan spiritualitas berperan terhadap tingkat depresi pada ibu hamil, self-compassion dan spiritualitas memiliki peran yang signifikan terhadap depresi sebesar 40,8 \% (Chairunnisa \& Fourianalistyawati, 2017).

Dengan demikian, berdasarkan hal di atas, ibu hamil khususnya dengan kondisi risiko tinggi, dapat mempertimbangkan pendekatan mindfulness ini sebagai salahsatu solusi untuk mengurangi masalah psikis dan meningkatkan kesehatan fisiknya.

\section{Daftar Pustaka}

Akhyar, Y. (2010). Deteksi Ibu Hamil Resiko Tinggi (Bumil Risti) Di Posyandu. Diunduh tanggal 20 Februari 2013 dari http://yayanakhyar.wordpress.com/2010/05/11/ deteksi-ibuhamil-resiko-tinggi-bumil-risti-di-posyandu/

Brown, K. W. \& Ryan, R. M. (2003). The benefits of being present: Mindfulness and its role in psychological well-being. Journal of Personality and Social Psychology, 84(4):822-848.

Chairunnisa, A \& Fourianalistyawati, E. (2017). The Role of Self-Compassion and Spirituality Toward Depression Among Pregnant Women. Presented in ASIA International Multidisciplinary Conference.

Fauzy, R. \& Fourianalistyawati, E. (2016). Hubungan antara Depresi dengan Kualitas Hidup pada Ibu Hamil Berisiko Tinggi. Jurnal Psikogenesis, Vol 4, no 2, Desember 2016.

Febriani, Z. Fourianalistyawati, E. \& Caninsti, R. (2017). The Effectiveness of Mindfulnessbased Training on Pregnancy Stress. Dipresentasikan di Conference: 3rd Asean Conference On Psychology, Counseling and Humanities, 2017. Malang: Universitas Muhammadiyah Malang.

Fourianalistyawati, E. \& Caninsti, R. (2014). Gambaran Kualitas Hidup pada Ibu dengan Kehamilan Risiko Tinggi. Dipresentasikan pada Konferensi Nasional II Universitas YARSI, Jakarta, 2014. Jakarta: Fakultas Psikologi Universitas YARSI.

Hughes, A., Williams, J. M. G., Bardacke, N., Duncan, L. G., Dimidjian, S., \& Goodman, S. H. (2009). British Journal of Midwifery, 17(10): 630-5.

Venkata C. \& Venkatashiah S. B. 2009. Sleep Disordered Breathing During Pregnancy. The Journal of the American Board of Family Medicine 22(2):158-168. 